\title{
Design of Vat Information System to Minimize Administrative Tax Sanctions
}

\author{
Suci Pratiwi, Waluyo* \\ Master of Accounting, Universitas Indonesia, Jakarta, Indonesia \\ *Corresponding author. Email: waluyo9@yahoo.com
}

\begin{abstract}
The Republic of Indonesia's government appoints certain business entities as Value Added Tax collectors (VAT), based on Regulation of the Minister of Finance of the Republic of Indonesia 37/PMK.03/2015. This creates problems for other companies, especially companies that are subsidiaries of certain business entities owned by state-owned enterprises. This study aims to examine the ideal design of a VAT information system, using Performance Information Economics Control Efficiency Services (PIECES) indicators, to reduce administrative tax sanctions. The study uses a mixed-method research approach. The results of the study conclude that a VAT-management information system that creates synergy between the head office and work units is needed, so that the issuance of tax invoices can be timely, to reduce the risk of VAT administrative sanctions. In addition, the company needs support from management, networks, adequate employee knowledge, and socialization regarding changes in the VAT-management information system.
\end{abstract}

Keywords: Information System, Value-Added Tax, Administrative Sanctions, PIECES

\section{INTRODUCTION}

Indonesia's sources of state income include tax revenues, nontax state revenues, and grants. The biggest state income comes from tax revenues, which rose by Rp. 8.7 trillion from the 2018 RAPBN. The biggest portions of this were Rp. 6.5 trillion from VAT and Rp. 2.2 trillion from oil and gas income tax (Kementerian Keuangan Republik Indonesia, 2018). Indonesia has three tax-collection systems that are recognized for tax revenues-namely, the self-assessment system, official assessment system, and withholding assessment (Waluyo, 2011). With the tax-collection system, taxpayers can deposit and report taxes independently, in accordance with applicable tax procedures.

The government also applies budget users or the representative ofbudget-user proxies and/or treasurers who make payments at the expense of the state budget, set as mandatory tax collection in accordance with the provisions of the laws and regulations (Kementerian Keuangan Republik Indonesia, 2003). In addition, the government also appoints certain business entities as VAT collectors. The appointment is based on Regulation of the Minister of Finance of the Republic of Indonesia 37/PMK.03/2015, concerning the appointment of certain business entities to collect, deposit, and report VAT alone or VAT and sales tax on luxury goods, and concerning the procedures for doing so. These business entities include state-owned enterprises that have been restructured by the government, business entities engaged in fertilizer, and certain business entities owned by state-owned enterprises (Keuangan, 2015).

The appointment of a certain business entity as a tax collector can raise the potential for overpayment of VAT, such that companies may apply for restitution of VAT, in accordance with the provisions of 2009's Law 42 about VAT and sales tax on luxurious goods. A VAT refund occurs because a taxpayer is selling taxable goods/services to a VAT collector. Submitting for restitution of VAT increases the potential of a tax audit, which can result in tax penalties for a company (Siregar, 2005).

As an example, a company affected by the Regulation of the Minister of Finance of the Republic of Indonesia 37/PMK.03/2015 is a subsidiary of a certain business entity owned by state-owned enterprises. During the refund process for VAT overpayment, the company may undergo a tax audit, resulting in administrative sanctions and, therefore, financial losses for the company.

The costs of such administrative sanctions include a fine, as per tax law article 14 (4), and a $100 \%$ increase 
on the amount VAT was underpaid. The company is subject to administrative sanctions because the tax invoice was not submitted in a timely manner, and income tax law states that tax invoices are to be issued in accordance with a submission period. The tax sanctions due to VAT then increase the taxable income and corporate income tax for the current year, such that net income after corporate tax for the current year decreases.

This study aims to examine how the design of taxation information systems is ideal for companies to reduce tax sanctions. This study has limited scope of only one company from 2014 until 2017, selected to show how much tax sanctions impact VAT as a result of changes in the status of a majority of shareholders from non-VAT collectors to VAT collectors. The year 2014 was the year before the status change occurred, 2015 was the status change transition year, and 2016-2017 was the year after the status change from non-VAT collector to VAT collector for the majority of shareholders. Accordingly, the research benefits are evaluation, analysis, providing solutions, and providing information for decision-making (Ellet, 2007). This research expects to provide companies further benefits, including analyzing the current tax-management accounting information system and providing recommendations regarding the VAT-management accounting information system. This study uses the contingency accounting theory of management, which states that a management accounting information system is influenced by determined aspects of the system environment itself (Otley, 2014). This research uses case-study strategies of companies with mixed-method research, utilizing such research instruments as questionnaire, interview, and content analysis. This study consists of five parts-namely, introduction, literature study, research methodology, results and discussion, and research conclusions.

\section{LITERATURE REVIEW AND HYPOTHESIS DEVELOPMENT}

\subsection{Accounting Information System}

One prior study on accounting information systems is Lucia's research (Lucia et al., 2013), which examines accounting data, information, and knowledge as an important component in a company-asset-position analysis and assessment, and also examines management motivation as the core of information systems. The study concludes that the purpose of an accounting information system is to provide information that synergizes between a company's operations, management systems, and internal and external environmental factors as part of an information user's decision-making process. Another study related to accounting information systems is Myskova's study
(2009), which concludes that an accounting information system serves as a connector for every information system supporting a company's financial-accounting management. It further concludes that an accounting information system supports management decisionmaking and is associated with external accounting and data-storage modules. Yet another study, conducted by Floropoulos, Spathis, Halvatzis, and Tsipouridou (2010), states that the success of tax information systems in Greece is influenced by several variables: information, system, and service quality, benefits obtained, and system-user satisfaction.

\subsection{Value-Added-Tax System}

The previous research regarding VAT collection and deposit systems includes a study conducted by Wardhani and Utama (2018), which aims to provide an accounting information systems plan for the VAT collector's process of collecting and depositing VAT. The study concludes that the implementation of e-tax payment is expected to improve the efficiency of VAT collection.

Based on previous studies, it is concluded that information systems are needed to improve the effectiveness of a company's business processes, including taxation management, and that a system's success is affected by system environment factors. This research differs from related studies because it focuses on the design of a company's VAT-management accounting information system. With the appropriate VAT-management accounting information system, it is expected that a company's potential tax sanctions could be reduced.

\subsection{Research Framework}

This study's main issue is company shareholders' 2015 status change from non-VAT collectors to VAT collectors. As a result, the company overpaid VAT, and then filed for a refund of the overpayment, in accordance with 2009's Law 42 about VAT and in accordance with the "VAT of Luxurious Goods" law. Accordingly, the Directorate General of Taxes checked the restitution submission. The tax audit resulted in the company experiencing financial losses from tax sanctions imposed by the Directorate General of Taxes due to the company's delay in issuing tax invoices. The tax penalties resulted in an increase in outside operating expenses and corporate income tax and a decrease in net income after tax during that period.

To overcome this issue, the active taxmanagement accounting information system is first evaluated. Then, using Otley's contingency theory of management accounting, the factors that influence the information system are examined. By selecting the right 
tax-management accounting information system, it is expected that the tax sanctions imposed on a company can be minimized. Company profits and cash should subsequently increase, and these can be used effectively and efficiently for operational activities or investments. The research framework depicted in FIGURE I.

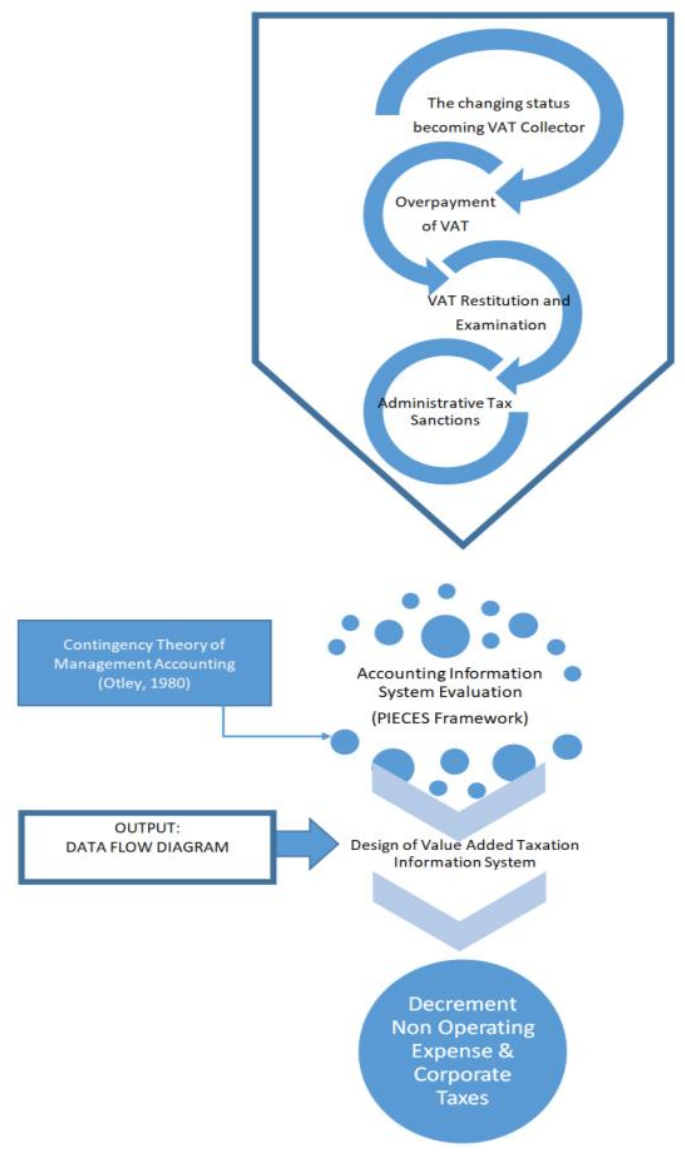

Figure I. Research framework

\section{RESEARCH METHOD}

This study used mixed-method research to enrich data analysis and develop new modes of thinking by attending to the paradoxes that emerge from utilizing two data sources (Shauki, 2018).

\subsection{Data Collection}

In the research-planning stage, the quantitative data used was from the 2015-2017 financial statements processed in case identification. In the data collection stage, the research instruments used were interviews, questionnaires, and content analysis.

The primary data was obtained by distributing questionnaires and interviewing users of tax information systems at PT XYZ. Through the questionnaire, users' needs from a tax-management accounting information system were determined. Interviews were used to dig deeper into companies' ideal tax-management accounting information system. Internal company documents related to corporate tax management were collected, and documentation related to company taxation policies was carried out.

\subsection{Data Analysis}

This study uses single-case analysis, which provides a deeper understanding of the research topic. PT XYZ, the subject of the research, is a private company that 99.9\% of its share capital is owned by a subsidiary of a state-owned enterprise. Most of the Company's sales transactions related to its Parent Company who is VAT collector. As a result, the Company's VAT always in overpayment position.

Content and descriptive analyses were used in this study's data analysis phase. Content analysis involved inspecting documents related to VAT-management, examining questionnaire results for questions related to tax-management information systems, and grouping questionnaire answers to be used in designing the company's VAT information system. The questionnaire combines open and closed questions, and it was given to people familiar with PT XYZ's taxation system, namely tax supervisors, senior tax executors, informationtechnology supervisors, and treasury senior executors. Content analysis was also used to study company policies and procedures, financial reports, and tax laws. Descriptive analysis consisted of drawing conclusions from the interview results. From the data collected, it was determined what the important aspects of the company's VAT-management information system were for each respondent.

\section{RESULTS AND DISCUSSION}

\subsection{Interview}

The VAT mechanism commonly used by companies is a credit method (output tax minus input tax). The impact of regulation 37/PMK.03/2015 on the company is that related parties' VAT output for income cannot be credited with the company's VAT input. As a result, companies overpay VAT. In the Republic of Indonesia's 2009 Law 42, Article 9 states that any VAT overpayment can be submitted for return/restitution. After restitution is requested, the next step is a tax audit. From the tax audit results, tax-administration sanctions can be imposed on the company. These taxadministration sanctions are related to tax invoices that are not reported on time.

Interviews were conducted with respondents regarding any factors that might result in a delay in issuing the tax invoice.

"Tax sanctions, because our output tax invoice is not in accordance with the finishing report period. So, if the 
news is November, we will only make December-it will be too late.” (Respondent 1, 2019)

"Actually, VAT overpayment is not a problem for the company. It's just that, when the late tax invoice checks are difficult if the minutes are late, then the tax invoice is too late [and the company] must be fined." (Respondent 2, 2019)

Based on the answers submitted by respondents one and two, it is known that the delay in publishing the minutes of work completion is the main cause of the delay in issuing tax invoices.

\subsection{Document Analysis}

To determine the company's ideal VATmanagement information system, interviews were conducted and policies and procedures related to the company's current VAT-management business process were studied. Interview results, policies, and procedures related to business processes were considered through content analysis. Based on the documents and explanations obtained, the company's tax-management process consists of the business processes depicted in FIGURE II. Business/event processes carried out by the company include VAT verification, recap, deposit (underpayment), refund submission, and reporting. Business processes related to VAT management are carried out by tax supervisors and senior tax executors. Tax supervisors are responsible for ensuring senior tax executors' work quality in accordance with applicable company policies, whereas senior tax executors carry out VAT verification activities, recaps, deposits, and reports for the period or annual VAT. Tax invoices are created by the tax supervisor. Filing for VAT refunds is completed jointly by the tax supervisor and the senior tax executor. The financial manager acts as the second reviewer and first approver. The finance director acts as the second approver.

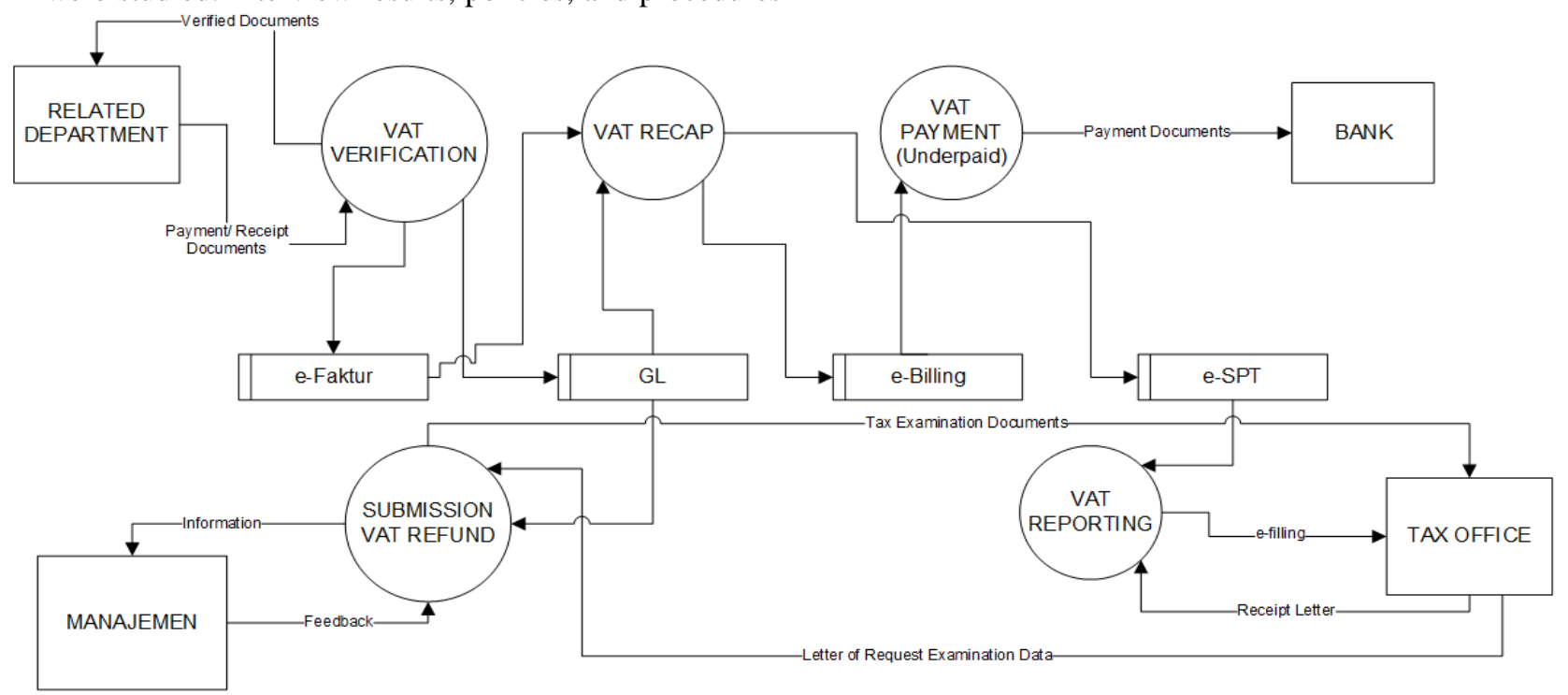

Figure II. Data-flow diagram-Centralized system

\subsection{Questionnaire}

A questionnaire that includes both open-ended and closed questions was used. Distributed questionnaires had a return rate of $50 \%$, despite recipients having been reminded to answer the questionnaire. The questionnaire was examined using constant comparative analysis. In developing the existing tax information system, closed questions related to Performance Information
Economics Control Efficiency Services (PIECES) indicators were used, which focus on the opinions of respondents regarding the need for tax information systems or not to improve performance, information (and data), economics (cost control, increased profits), control (and security), efficiency, and services (Whitten and Bentley, 2007). The questionnaire was used to assess users' needs according to the PIECES indicators. The questionnaire results are as follows. 


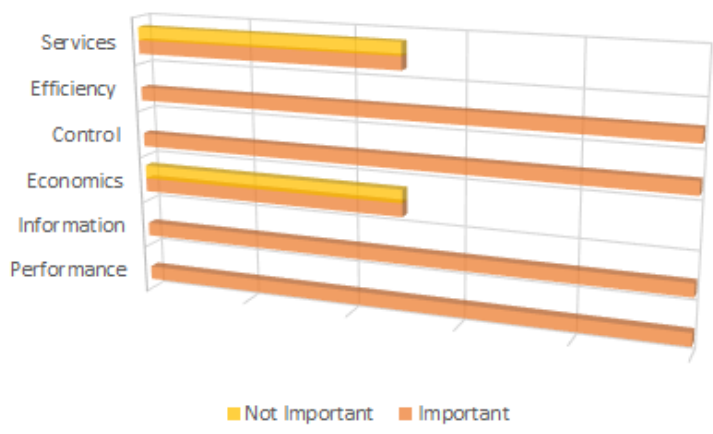

Figure III. Pieces questionnaire result

Based on the research data, the respondents state that performance, information (and data), control (and security), and efficiency are important indicators that need to be developed in the corporate tax management accounting information system. The "economics" indicator is not important for $50 \%$ of respondents who use applications from the directorate general of taxes without being charged. The rest of respondents answered in "economics" indicator that the system needs to be developed to control the company costs. "Services" is an important indicator for 50\% of respondents because, with a good tax information system, the company will be easier to get the valid and accurate information.. It can therefore be concluded that the company requires the development of an information system that can mitigate tax-management risks related to corporate VAT.

In addition to closed questions, open-ended questions were also asked relating to tax-management information system needs, such as what respondents desire and their satisfaction with the existing information system. Respondents already felt quite satisfied with the existing VAT-management information system because of advantages such as low purchase value and ease of use, but several potential areas for development in the VAT-management information system were also named.

The questionnaire answers were processed using NVivo 12 Plus by analyzing word frequency. The top words used most often by respondents to describe their needs for tax-management information systems were selected. The results of the word frequency analysis are as follows: risk, ease, understandable, policy, reliable, updating, database, accuracy, and socialization.

\subsection{Discussion}

Based on the interview results and document analysis that have been conducted, the results are as follows.

a. Based on the answers given by interview respondents one and two, it was determined that the main cause of the late tax invoices was delays in recording work-completion minutes. One example is that of the operation and maintenance service providers for the period of October 2017, where the minutes for the completion of new work were not signed by all parties until December 2017, such that the related tax invoices were issued in December 2017. The delay in issuing these tax invoices made the company subject to a fine, under article 14 (4) KUP. Processes involving recording work-completion minutes, creating tax invoices, and preparing other billing files are still done centrally at the head office, as part of the centralized system used by the company. A comparison of the answers given by respondents one and two is shown in TABLE I.

Table I. Comparison between respondents one and two

\begin{tabular}{|l|l|l|}
\hline Question & Respondent 1 & Respondent 2 \\
\hline $\begin{array}{l}\text { 1. Why does the company } \\
\text { experience VAT overpayments? }\end{array}$ & $\begin{array}{l}\text { Changes in the status of related parties } \\
\text { from non-VAT collector [to] VAT } \\
\text { collector }\end{array}$ & $\begin{array}{l}\text { The VAT overpayment occurred } \\
\text { because the parent company as VAT } \\
\text { collector since April 2015. }\end{array}$ \\
\hline $\begin{array}{l}\text { 2. Why did PT XYZ experience tax } \\
\text { penalties on VAT? }\end{array}$ & $\begin{array}{l}\text { This is because [, due to] the delay in } \\
\text { issuing tax invoices [, they do] not } \\
\text { match the period of completion of the } \\
\text { work. Making tax invoices based on } \\
\text { minutes received from relevant } \\
\text { departments }\end{array}$ & $\begin{array}{l}\text { Overpayment of VAT is not a problem } \\
\text { for PT XY. [The problem is the } \\
\text { completion of work, which is one of } \\
\text { the reasons for PT XYZ to [receive] } \\
\text { tax sanctions on VAT. }\end{array}$ \\
\hline
\end{tabular}


b. The results of the document analysis provide an overview of business processes and what applications are used in the company.

c. The questionnaire results indicate that the respondents hope the VAT-management information system could mitigate tax risks, provide data and reliable, accurate, and upto-date information conveniently, be easy to understand and based on policies that support the company's business processes, and present the company's policy clearly to all employees.

The VAT design in FIGURE IV is based on the research results. VAT verification is a business process that consists of several sub processes-namely, payment verification and creating tax invoices. Previously, these processes were carried out centrally, with tax invoices being issued once all parties had submitted their workcompletion minutes. Based on the interview results, the length of time the process took to submit the workcompletion minutes was the cause of the lateness in issuing the tax invoices. This can be mitigated by issuing tax invoices together with the draft minutes issued at the end of every month. The difference between the current business process and the recommendation is whether the tax invoices are issued in units or at the head office, which can be adjusted according to the location of the parties who sign off on the minutes. By issuing tax invoices in a timely manner, the company is able to mitigate the risk of VAT administrative sanctions. Should there be a nominal change in the work minutes, the company can make corrections to the issued tax invoice.

After VAT verification process, the next business process is the VAT recap, deposit (underpayment), and refund submission, similar to the ongoing business process as described in FIGURE II. The following difference is in the VAT-reporting business process. With the recommendations given, the company can make corrections to SPT every month, due to nominal changes in the work-completion minutes, resulting in changes to the base tax imposition on tax invoices.

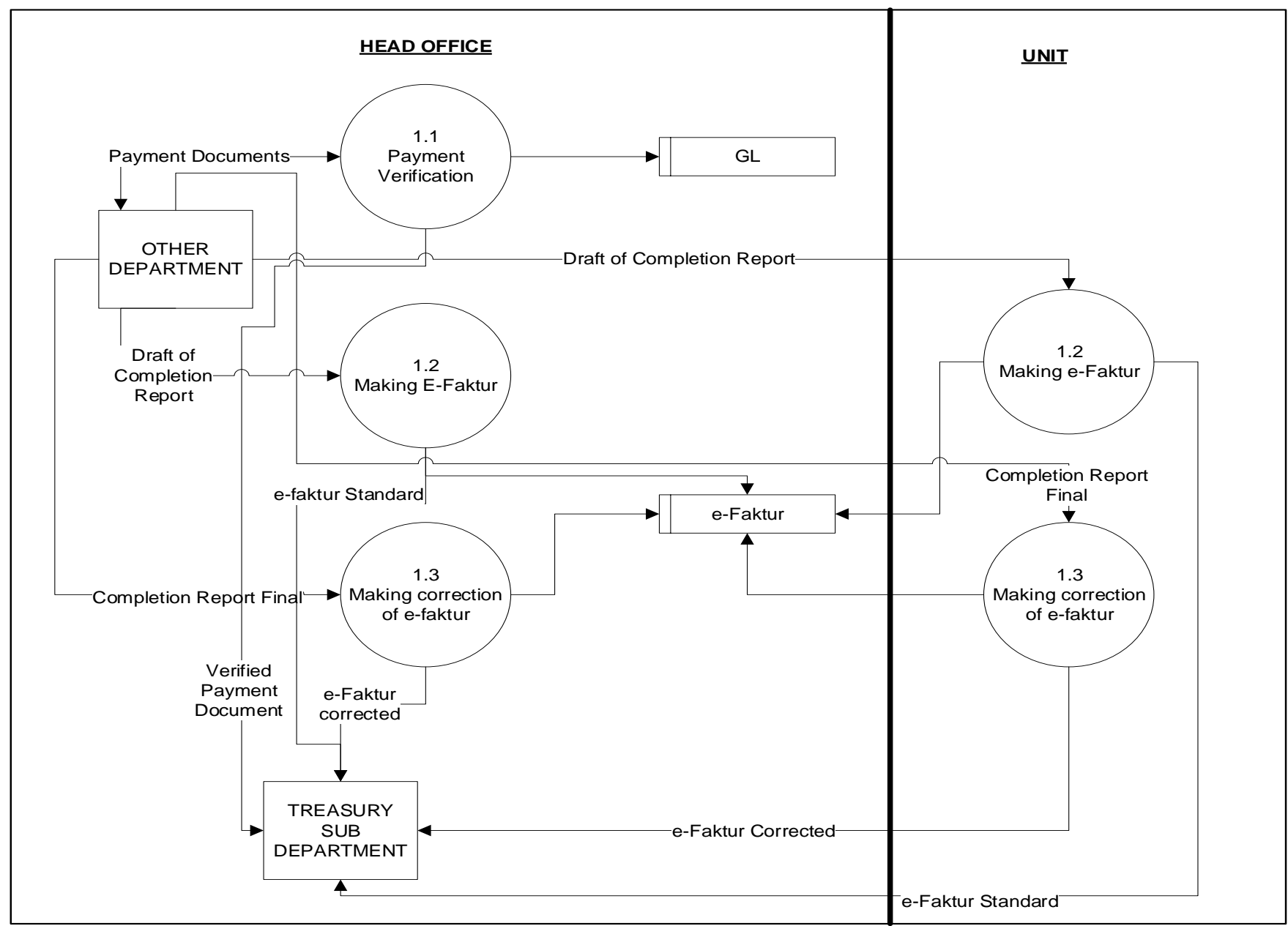

Figure IV. Data-flow diagram

The study results indicate that the synergy between units and headquarters needs to be increased to reduce the risk of VAT administrative sanctions. Other supporting factors that need to be considered in the 
implementation of information systems are management support, networks, and adequate employee knowledge as well as presentation related to changes in the VATmanagement information system. This is in accordance with management accounting contingency theory, which states that contingency theory must identify specific aspects of the information system that are related to predetermined environmental conditions and reflect system conformity. In addition, this information system's design aims to meet the expectation of having a VAT-management information system that can mitigate tax-related risks, provide data and reliable, accurate, and up-to-date information with facility, be easy to understand, and support the company's business processes.

\section{CONCLUSION AND IMPLICATIONS}

Based on the previously discussed research results, it can be concluded that this company's ideal VATmanagement information system, designed to reduce VAT administrative sanctions, is one that creates synergy between the head office and work units, as illustrated in FIGURE III. In addition, the company needs support from management, networks, and adequate employee knowledge as well as socialization regarding changes to the VAT-management information system.

\section{RESEARCH LIMITATIONS}

This study has limitations in terms of the scope of the research object under study, which is not extensive, being limited to only one company and its VATmanagement information system, such that the study results cannot be generalized. The proposal for further research is to expand the object of research, such that the business of the chosen research object can be more varied.

\section{REFERENCES}

[1] Ellet, W.(2007) The Case Study Handbook.

[2] Floropoulos, J., Spathis, C., Halvatzis, D., and Tsipouridou, M., (2010) "Measuring the success of the Greek Taxation Information System," Int. J. Inf. Manage., vol. 30, no. 1, pp. 47-56.
[3] Kementerian Keuangan Republik Indonesia, "Apbn 2018,” Kementerian Keuangan Republik Indonesia.

p. https://www.kemenkeu.go.id/apbn2018,

[4] Kementerian Keuangan Republik Indonesia, (2003) "KMK 563 tahun 2003, Bendaharawan sebagai pemungut PPN,"Kementerian Keuangan Republik Indonesia.

[5] Keuangan, P. M. (2015) http://jdih.bpk.go.id/wpcontent/uploads/2015/12/PERATURANMENTERI-KEUANGAN-NOMOR-37-PMK.032015.pdf.

[6] Lucia, P., Ph, D., Brancusi, C., and Jiu, T., (2013) "Accounting: An essential component of the information system 2. Accounting information and its importance in decision making, no. 1, pp. 6673, 2013.

[7] Myšková, R., (2009) “Company information systems used in decision-making processes of financial managers," WSEAS Trans. Syst., vol. 8, no. 4, pp. 532-542, 2009.

[8] Otley, D. "The contingency theory of management accounting and control : 1980 - 2014 David Otley The contingency theory of management accounting and control :," pp. 1980-2014, 2014.

[9] Siregar, Y. N. S. (2005) "Bribing a fee in indonesian value added tax refund," no. Policy Research Institute, Ministry of Finance.

[10] R., (2018) "Research Instruments in Case Study and the Role of Researcher," Handout, Case Writing and Methodology, Ecam 809303, (Elvia R. Shauki, PhD). University of Indonesia, Print.

[11] Waluyo, (2011) Perpajakan Indonesia Edisi 10Buku 1, Jakarta: Salemba Empat.

[12] Wardhani A. R. and Utama, A. G. S. (2018) "Evaluasi Dan Desain Sistem Informasi Akuntansi Pemungutan Dan Penyetoran Ppn Dalam Upaya Meningkatkan Efisiensi Kinerja Subdinas Perpajakan Pada Pt. Pelabuhan Indonesia Iii (Persero) Cabang Tanjung Perak," J. Ris. Akunt. Dan Bisnis Airlangga, vol. 1, no. 1, pp. 37-46. 